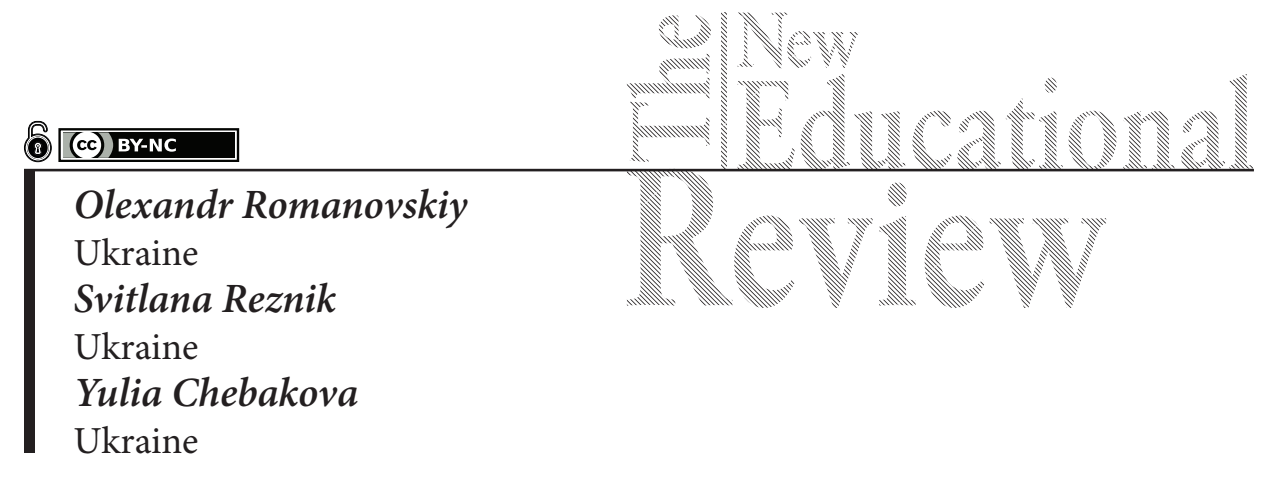

\title{
Peculiarities of Perception of Teaching Style and Motivation of Students' Learning
}

DOI: 10.15804/tner.2019.58.4.05

\begin{abstract}
The objective of the article is to study the peculiarities of students' perception of teaching style and to determine the correlation between such perception and motivation of students' learning. The group of respondents included 254 future social and 156 technical specialists (a total of 410 students), methods of research were questioning and testing; Pearson correlation coefficient was used for statistical analysis. Students perceived the democratic teaching style as the most positive, and its use is associated with educational and cognitive motives. Authoritarian and laissez faire styles are seen as undesirable. The first is related to the motives of avoidance, and the second has feedback from professional motives of students. Comparison of the results of the survey of future social and technical specialists allowed us to determine that the latter perceive the authoritarian style more positively than students of social specializations.
\end{abstract}

Key words: teacher leadership style, style of pedagogical communication, motivation of student learning.

\section{Introduction}

Students' perception of teachers is important to learning outcomes (Nabaho, Oonyu \& Aguti, 2017) and can impact students' motivation (Noels, Clement, \& 
Pelletier, 1999). In our study, we focus on students' perception of teaching style and analyze its relation to students' learning motivation. It is important that teachers understand how students perceive teaching style, because it will help to improve teaching and the learning achievements of students (Hanaa, Atyat, \& Heba, 2018).

The analysis of the style of a teacher through the prism of leadership is associated in particular with the management of an educational group of students (Barni, Russo, \& Danioni, 2018; Bota \& Tulbure, 2017; Sadik, 2016). Different authors classify teaching style in different ways: authoritarian, authoritative, and permissive styles (Barni et al., 2018; Thijs \& Verkuyten, 2009); authoritarian, democratic, indulgent/populist, passive/minimal, median (Bota \& Tulbure, 2017); authoritarian, democratic, laissez faire and indifferent (Hanaa et al., 2018; Munir \& Rehman, 2016); autocratic, democratic, laissez faire (Dahar, Faize, Niwaz, Hussain, \& Zaman, 2010; Doll, 1947; Sadik, 2016); authoritarian, democratic (Sobkin \& Kalashinikova, 2016). Analysis of these works allows us to note that, despite the different classifications, the criteria for determining the leadership style of the teacher are often control of and attitude to (interest in) students. The democratic (authoritative) style is characterized as maximum control and interest, attention, warmth to the students; the authoritarian (autocratic) style is characterized as a manifestation of maximum, strict control and detachment from the students; the laissez faire (permissive, passive) style - a minimum of control and indifference to the students. In our research we used the authoritarian, democratic, laissez faire classification of teacher leadership styles.

To better understand the peculiarities of students' perception of teaching style, we decided to analyze the relationship between students' perception of teacher leadership styles and the styles of pedagogical communication defined by Kan-Kalik (1987). He identified five styles of pedagogical communication: based on interest in joint activities (this style is based on high professionalism of the teacher, the ability to interest the student, to attract him/her to cooperate and be active), on the basis of amiability (characterized by communication based on a friendly, warm attitude towards students), communication-distance (associated with the status, age, experience, and knowledge of the teacher, which define a certain distance between him/her and students), communication-intimidation (characterized in communication by an emphasis on the negative consequences for students of undesirable behavior in academic work or discipline), communication-flirtation (meaning trying to gain credibility using unlawful, unethical means, being over-familiar, conniving with students over errors, being condescending as a result of uncertainty and lack of professionalism of the teacher). The first two styles are the most positive and productive for the results of teaching; the last two 
are undesirable and negative, while the style communication-distance can be both positive and negative (Kan-Kalik, 1987).

The purpose of the research is:

1. Study of features of students' perception of the teaching style of educators, based on analysis of the relationship between styles of pedagogical communication and leadership styles of teachers.

2. Determining the correlation between students' perception of teaching style and their learning motivation.

3. Comparison of features of perception of the teaching style of educators and the relationship of this perception with the learning motivation of future social and technical specialists.

\section{Methodology}

The study was conducted at the National Technical University "Kharkiv Polytechnic Institute" (Ukraine), the structure of which includes five educational and scientific institutions, a military institute and 4 faculties. Students were sent 754 letters with an invitation to participate in the survey and testing, 433 answers were received, some of which were incomplete, that is, some questions of the questionnaire or test were not answered. Thus, in general, the statistical analysis and interpretation covered answers of 410 students, including 254 from future social specialists (future teachers, psychologists, managers), and 156 from future technical specialists (future engineers of various specialties).

To study features of the perception of teaching style, a questionnaire was developed, which included two questions. The first provided an assessment by students of how common styles of pedagogical communication according to the classification of Kan-Kalik (1987) are. Students were asked to assess each style as a percentage from 0 to 100 , according to their idea about which communication styles were used by teachers to a greater or lesser extent in their training in the higher educational institution.. Students were also asked to rate the prevalence among their teachers of the authoritarian, democratic, and laissez faire teaching styles as a percentage from 0 to 100 .

For the evaluation of motivation a technique developed by Rean and Yakunin, a modification of Badmaeva (2004), was used to diagnose the educational motivation of students. The methodology consists of seven scales: 
- communicative motives, which include the desire to gain new knowledge, as it helps the student to communicate better and work with interesting people, and gives more confidence and authority in the team;

- educational and cognitive motives which suggest the student's urge to obtain new knowledge, the desire to learn successfully, because they like the learning process;

- professional motives which are based on the propensity for a particular profession, the student learns because they like the chosen profession;

- social motives which mean learning to obtain a certain status in society or material well-being, the desire to benefit society or to do a duty to other people;

- the motives of avoidance which include the desire to avoid negative marks, fear of being among the lagging students, showing themselves in an unfavorable light, being academic losers;

- motives of creative self-realization which are based on the desire to engage in creative activity;

- prestige motives which mean the need to be among the best students, to gain approval, to have a good reputation as a capable, successful student, to have advantages among others due to academic performance.

Educational motivation was rated using 34 statements. These are a description of a certain motive of educational activity, each of which students were asked to rate on a 5-point scale: where 1 point corresponded to the motive being of minimum significance and 5 - to its being of maximum significance. When processing the results of each motivational scale, the arithmetic mean of students' scores was determined (Badmaeva, 2004).

Since the results of the student survey were measured using ratio and interval scales, Pearson's correlation coefficient was used for statistical analysis. 


\section{Results}

The results of the correlation analysis concerning the peculiarities of students' perception of the teaching style are presented in Table 1.

Table 1. Students' perception of teaching style: correlation between pedagogical communication styles and teachers' teaching styles

\begin{tabular}{|c|c|c|c|c|c|c|c|c|}
\hline $\begin{array}{l}\text { Teaching } \\
\text { style }\end{array}$ & $\begin{array}{c}\text { Based } \\
\text { on the } \\
\text { interest } \\
\text { in joint } \\
\text { activities }\end{array}$ & $\begin{array}{c}\text { Amiabil- } \\
\text { ity }\end{array}$ & $\begin{array}{l}\text { Com- } \\
\text { munica- } \\
\text { tion-dis- } \\
\text { tance }\end{array}$ & $\begin{array}{l}\text { Com- } \\
\text { munica- } \\
\text { tion-in- } \\
\text { timida } \\
\text { tion }\end{array}$ & $\begin{array}{l}\text { Com- } \\
\text { munica- } \\
\text { tion-flir- } \\
\text { tation }\end{array}$ & $\begin{array}{c}\text { Authori- } \\
\text { tarian }\end{array}$ & $\begin{array}{l}\text { Demo- } \\
\text { cratic }\end{array}$ & $\begin{array}{l}\text { Laissez } \\
\text { faire }\end{array}$ \\
\hline $\begin{array}{l}\text { based on } \\
\text { the interest } \\
\text { in joint } \\
\text { activities }\end{array}$ & 1 & $.427^{\star *}$ & $.247^{\star *}$ & -.045 & -.049 & $.179^{\star *}$ & $.351^{\star *}$ & -.086 \\
\hline amiability & & 1 & $.194^{\star \star}$ & -.042 & $.139^{\star *}$ & .050 & $.405^{\star *}$ & .005 \\
\hline $\begin{array}{l}\text { communi- } \\
\text { cation-dis- } \\
\text { tance }\end{array}$ & & & 1 & $.307^{\star *}$ & $.237^{\star *}$ & $.359^{* *}$ & .035 & $.264^{* *}$ \\
\hline $\begin{array}{l}\text { communi- } \\
\text { cation-in- } \\
\text { timidation }\end{array}$ & & & & 1 & $.302^{\star *}$ & $.313^{* *}$ & $-.231^{\star \star}$ & $.312^{\star *}$ \\
\hline $\begin{array}{l}\text { communi- } \\
\text { cation-flir- } \\
\text { tation }\end{array}$ & & & & & 1 & $.103^{\star}$ & $-.099^{*}$ & $.231^{\star *}$ \\
\hline $\begin{array}{l}\text { authoritar- } \\
\text { ian }\end{array}$ & & & & & & 1 & $-.351^{\star \star}$ & $.190^{\star *}$ \\
\hline democratic & & & & & & & 1 & $-.183^{\star \star}$ \\
\hline laissez faire & & & & & & & & 1 \\
\hline
\end{tabular}

${ }^{*}$ indicates $\mathrm{p}<.05 ;{ }^{* *}$ indicates $\mathrm{p}<.01$.

As can be seen from Table 1, according to the perception of students, the democratic style of teaching correlates with the styles of communication based on interest in joint activities $(\mathrm{r}=0.351, \mathrm{p}<0.01)$ and on the basis of amiability $(\mathrm{r}=0.405, \mathrm{p}<0.01)$, but negatively correlates with communication-intimidation $(\mathrm{r}=-0.231, \mathrm{p}<0.01)$ and communication-flirtation $(\mathrm{r}=-0.099, \mathrm{p}<0.05)$.

Table 2 shows the results of the correlation analysis of the relationship between the peculiarities of students' perception of teaching style and their motivation for learning. 
Table 2. Correlation between students' perception of teaching style and their learning motivation.

\begin{tabular}{|c|c|c|c|c|c|c|c|}
\hline \multirow{2}{*}{$\begin{array}{l}\text { Teaching } \\
\text { style }\end{array}$} & \multicolumn{7}{|c|}{ Motives of students } \\
\hline & $\begin{array}{l}\text { commu- } \\
\text { nicative }\end{array}$ & avoiding & prestige & $\begin{array}{l}\text { profes- } \\
\text { sional }\end{array}$ & $\begin{array}{l}\text { creative } \\
\text { self-reali- } \\
\text { zation }\end{array}$ & $\begin{array}{l}\text { educational } \\
\text { and cogni- } \\
\text { tive }\end{array}$ & social \\
\hline $\begin{array}{l}\text { based on } \\
\text { the interest } \\
\text { in joint } \\
\text { activities }\end{array}$ & $.207^{\star *}$ & .034 & $.097^{\star}$ & .057 & .051 & $.149^{\star *}$ & $.138^{\star *}$ \\
\hline amiability & $.101^{\star}$ & .028 & .089 & -.024 & .066 & .092 & .095 \\
\hline $\begin{array}{l}\text { communi- } \\
\text { cation-dis- } \\
\text { tance }\end{array}$ & $.103^{\star}$ & .092 & $.098^{\star}$ & .016 & .056 & .039 & .018 \\
\hline $\begin{array}{l}\text { communi- } \\
\text { cation-in- } \\
\text { timidation }\end{array}$ & .087 & $.113^{*}$ & .061 & -.023 & .068 & .016 & .011 \\
\hline $\begin{array}{l}\text { communi- } \\
\text { cation-flir- } \\
\text { tation }\end{array}$ & -.046 & .088 & .005 & $-.098^{\star}$ & .070 & -.053 & -.073 \\
\hline $\begin{array}{l}\text { authoritar- } \\
\text { ian }\end{array}$ & $.100^{\star}$ & $.136^{\star *}$ & $.120^{*}$ & -.048 & .084 & .026 & .067 \\
\hline democratic & $.133^{\star *}$ & -.053 & .022 & .054 & .031 & $.103^{\star}$ & $.098^{*}$ \\
\hline laissez faire & -.076 & .021 & -.059 & $-.116^{*}$ & .084 & -.091 & $-.188^{\star *}$ \\
\hline
\end{tabular}

${ }^{*}$ indicates $\mathrm{p}<.05 ;{ }^{* *}$ indicates $\mathrm{p}<.01$.

As Table 2 shows, the democratic teaching style correlates with communicative $(\mathrm{r}=0.133, \mathrm{p}<0.01)$, social $(\mathrm{r}=0.098, \mathrm{p}<0.05)$ and educational-cognitive $(\mathrm{r}=$ $0.102, \mathrm{p}<0.05)$ motivation of students.

Peculiarities of perception of teaching style by future social and technical specialists are given in tables 3 and 4. 
Table 3. Perception of teaching style by future social specialists $(N=254)$

\begin{tabular}{|c|c|c|c|c|c|c|c|c|}
\hline $\begin{array}{l}\text { Teaching } \\
\text { style }\end{array}$ & $\begin{array}{l}\text { based on } \\
\text { the interest } \\
\text { in joint } \\
\text { activities }\end{array}$ & $\begin{array}{l}\text { amia- } \\
\text { bility }\end{array}$ & $\begin{array}{l}\text { com- } \\
\text { munica- } \\
\text { tion-dis- } \\
\text { tance }\end{array}$ & $\begin{array}{l}\text { communi- } \\
\text { cation-in- } \\
\text { timidation }\end{array}$ & $\begin{array}{l}\text { com- } \\
\text { munica- } \\
\text { tion-flir- } \\
\text { tation }\end{array}$ & $\begin{array}{c}\text { authori- } \\
\text { tarian }\end{array}$ & $\begin{array}{l}\text { demo- } \\
\text { cratic }\end{array}$ & $\begin{array}{l}\text { laissez } \\
\text { faire }\end{array}$ \\
\hline $\begin{array}{l}\text { based on } \\
\text { the interest } \\
\text { in joint } \\
\text { activities }\end{array}$ & 1 & $.412^{\star \star}$ & $.169^{\star *}$ & -.064 & -.081 & .119 & $.414^{\star *}$ & -.122 \\
\hline amiability & & 1 & $.156^{\star}$ & -.038 & $.143^{\star}$ & .072 & $.383^{\star *}$ & .007 \\
\hline $\begin{array}{l}\text { communica- } \\
\text { tion-distance }\end{array}$ & & & 1 & $.368^{\star *}$ & $.252^{\star \star}$ & $.403^{\star *}$ & .036 & $.297^{\star \star}$ \\
\hline $\begin{array}{l}\text { communica- } \\
\text { tion-intimi- } \\
\text { dation }\end{array}$ & & & & 1 & $.336^{\star *}$ & $.378^{\star *}$ & $-.265^{\star *}$ & $.421^{\star *}$ \\
\hline $\begin{array}{l}\text { communi- } \\
\text { cation-flirta- } \\
\text { tion }\end{array}$ & & & & & 1 & $.160^{\star}$ & -.118 & $.238^{\star \star}$ \\
\hline authoritarian & & & & & & 1 & $-.358^{\star *}$ & $.330^{\star *}$ \\
\hline democratic & & & & & & & 1 & $-.182^{\star *}$ \\
\hline laissez faire & & & & & & & & 1 \\
\hline
\end{tabular}

${ }^{*}$ indicates $\mathrm{p}<.05 ;{ }^{* *}$ indicates $\mathrm{p}<.01$.

Table 4. Perception of teaching style by future technical specialists $(N=254)$

\begin{tabular}{|c|c|c|c|c|c|c|c|c|}
\hline Teaching style & $\begin{array}{l}\text { based on } \\
\text { the interest } \\
\text { in joint } \\
\text { activities }\end{array}$ & $\begin{array}{l}\text { amia- } \\
\text { bility }\end{array}$ & $\begin{array}{l}\text { com- } \\
\text { munica- } \\
\text { tion-dis- } \\
\text { tance }\end{array}$ & $\begin{array}{l}\text { communi- } \\
\text { cation-in- } \\
\text { timidation }\end{array}$ & $\begin{array}{c}\text { com- } \\
\text { munica- } \\
\text { tion-flir- } \\
\text { tation }\end{array}$ & $\begin{array}{c}\text { authori- } \\
\text { tarian }\end{array}$ & $\begin{array}{l}\text { demo- } \\
\text { cratic }\end{array}$ & $\begin{array}{l}\text { laissez } \\
\text { faire }\end{array}$ \\
\hline $\begin{array}{l}\text { based on the } \\
\text { interest in } \\
\text { joint activities }\end{array}$ & 1 & $.454^{\star *}$ & $.378^{\star *}$ & -.015 & .010 & $.288^{\star *}$ & $.266^{\star *}$ & -.027 \\
\hline amiability & & 1 & $.264^{\star *}$ & -.052 & .135 & .008 & $.445^{\star \star}$ & .003 \\
\hline $\begin{array}{l}\text { communica- } \\
\text { tion-distance }\end{array}$ & & & 1 & $.206^{\star *}$ & $.204^{\star}$ & $.276^{\star *}$ & .050 & $.204^{\star}$ \\
\hline $\begin{array}{l}\text { communica- } \\
\text { tion-intimida- } \\
\text { tion }\end{array}$ & & & & 1 & $.245^{\star *}$ & $.194^{\star}$ & $-.194^{*}$ & .129 \\
\hline $\begin{array}{l}\text { communica- } \\
\text { tion-flirtation }\end{array}$ & & & & & 1 & -.014 & -.046 & $.213^{\star *}$ \\
\hline authoritarian & & & & & & 1 & $-.354^{* *}$ & -.074 \\
\hline democratic & & & & & & & 1 & $-.175^{\star}$ \\
\hline laissez faire & & & & & & & & 1 \\
\hline
\end{tabular}

${ }^{*}$ indicates $\mathrm{p}<.05$; ${ }^{* *}$ indicates $\mathrm{p}<.01$. 
As can be seen from Tables 3 and 4, students of both social and technical specializations associated the democratic style of teaching with styles of pedagogical communication based on interest in joint activities, and on the basis of amiability, while they felt it has a negative correlation with communication-intimidation. Both groups perceived the authoritarian style as associated with communication-distance, and communication-intimidation, but there are differences in the fact that students of social specializations associate it even with communication-flirtation, while students of technical specializations associate it with communication based on interest in joint activities. Perception of the laissez faire style is different, because students of social specializations associate it with communication-intimidation, and students of technical specializations do not.

The results of the analysis of the correlation between future social and technical specialists' perception of teaching style and their motivation for learning are shown in Tables 5 and 6.

Table 5. Correlation between the future social specialists' perception of teaching style and their motivation for learning $(N=254)$

\begin{tabular}{lccccccc}
\hline \multirow{2}{*}{ Teaching style } & \multicolumn{7}{c}{ Motives of students } \\
\cline { 2 - 8 } & $\begin{array}{c}\text { commu- } \\
\text { nicative }\end{array}$ & $\begin{array}{c}\text { avoid- } \\
\text { ing }\end{array}$ & prestige & $\begin{array}{c}\text { profes- } \\
\text { sional }\end{array}$ & $\begin{array}{c}\text { creative } \\
\text { self-realiza- } \\
\text { tion }\end{array}$ & $\begin{array}{c}\text { educa- } \\
\text { tional and } \\
\text { cognitive }\end{array}$ & social \\
\hline $\begin{array}{l}\text { based on the } \\
\text { interest in joint } \\
\text { activities }\end{array}$ & $.196^{\star *}$ & .093 & .088 & .029 & -.041 & $.123^{\star}$ & .073 \\
\hline amiability & .058 & .053 & .085 & -.081 & -.002 & .082 & .088 \\
\hline $\begin{array}{l}\text { communica- } \\
\text { tion-distance }\end{array}$ & $.156^{\star}$ & $.194^{\star *}$ & $.137^{\star}$ & .060 & .084 & .068 & .040 \\
\hline $\begin{array}{l}\text { communica- } \\
\text { tion-intimidation }\end{array}$ & .078 & .076 & -.030 & -.052 & .063 & -.051 & -.076 \\
\hline $\begin{array}{l}\text { communica- } \\
\text { tion-flirtation }\end{array}$ & -.075 & .119 & .021 & -.122 & .085 & -.031 & -.022 \\
\hline authoritarian & .067 & $.225^{\star *}$ & .087 & -.092 & .085 & -.014 & .023 \\
\hline democratic & $.133^{\star}$ & -.081 & .008 & .022 & -.018 & .090 & .083 \\
\hline laissez faire & -.047 & .040 & -.087 & $-.202^{* *}$ & .096 & $-.146^{\star}$ & $-.209^{\star *}$ \\
\hline
\end{tabular}

${ }^{*}$ indicates $\mathrm{p}<.05 ;{ }^{* *}$ indicates $\mathrm{p}<.01$. 
Table 6. Correlation between the future specialists in technical fields perception of teaching style and their motivation for learning $(\mathrm{N}=254)$

\begin{tabular}{lccccccc}
\hline & \multicolumn{6}{c}{ Motives of students } \\
\cline { 2 - 8 } Teaching style & $\begin{array}{l}\text { commu- } \\
\text { nicative }\end{array}$ & avoiding & prestige & $\begin{array}{c}\text { profes- } \\
\text { sional }\end{array}$ & $\begin{array}{c}\text { creative } \\
\text { self-reali- } \\
\text { zation }\end{array}$ & $\begin{array}{c}\text { educa- } \\
\text { tional and } \\
\text { cognitive }\end{array}$ & social \\
\hline $\begin{array}{l}\text { based on the } \\
\text { interest in joint } \\
\text { activities }\end{array}$ & $.225^{\star *}$ & -.023 & .111 & .096 & $.185^{\star}$ & $.186^{\star}$ & $.237^{\star *}$ \\
\hline amiability & $.165^{\star}$ & .005 & .096 & .053 & $.164^{*}$ & .104 & .103 \\
\hline $\begin{array}{l}\text { communica- } \\
\text { tion-distance }\end{array}$ & .039 & -.012 & .033 & -.033 & .046 & .005 & -.010 \\
\hline $\begin{array}{l}\text { communica- } \\
\text { tion-intimida- } \\
\text { tion }\end{array}$ & .096 & $.160^{*}$ & $.216^{* *}$ & .010 & .065 & .109 & .145 \\
\hline $\begin{array}{l}\text { communica- } \\
\text { tion-flirtation }\end{array}$ & .020 & .057 & -.021 & -.040 & .102 & -.072 & -.150 \\
\hline authoritarian & $.160^{\star}$ & .046 & $.183^{*}$ & .020 & .092 & .093 & .145 \\
\hline democratic & .094 & -.022 & .034 & .047 & .002 & .088 & .097 \\
\hline laissez faire & -.109 & .001 & -.007 & .023 & .104 & .001 & -.148 \\
\hline
\end{tabular}

${ }^{*}$ indicates $\mathrm{p}<.05 ;{ }^{* *}$ indicates $\mathrm{p}<.01$.

As Tables 5 and 6 show, the future social specialists' perception of teachers using the authoritarian style is associated with motives of avoidance, and the future technical specialists' perception is associated with communicative motives and motives of prestige.

\section{Discussion}

According to the results obtained in the research, students perceive the democratic teaching style most positively, because they associate it with productive styles of pedagogical communication and, by contrast, negatively consider association with undesirable styles of teaching behavior, such as communication-intimidation and communication-flirtation. The authoritarian pedagogical style has both positive (communication based on interest in joint activities) and negative associations. Students assess the laissez faire teacher style as the worst, because they associate it solely with such forms of behavior as communication-distance, communication-intimidation and communication-flirtation. 
The results confirm other research, according to which the democratic (authoritative) style of teachers is the most acceptable (Bota \& Tulbure, 2017; Doll, 1947; Hanaa et al., 2018; Munir \& Rehman, 2016; Thijs \& Verkuyten, 2009), and laissez-faire (passive, permissive) is regarded the most negatively (Bota \& Tulbure, 2017; Dahar et al., 2010; Thijs \& Verkuyten, 2009).

In addition, the results of our study confirm the representation of Kan-Kalik's (1987) style of communication-distance as the most common, because we revealed its relationship with all other teaching styles, except the democratic. It should be noted that communication-distance can be a natural phenomenon and is observed even in amiable communication, because it is based on the experience, knowledge, and status of the teacher, but in its extreme manifestations distance means detachment and closeness of the teacher, which, we assume, may be characteristic of such teaching styles as authoritarian, laissez faire, communication-intimidation and communication-flirtation.

Badmaeva (2004) points out that the most favorable motivations for academic performance are educational and cognitive, professional and motivation for creative self-realization. Exactly these motives belong to the inner ones. The least favorable is the motivation of avoidance, because it leads to negative emotions and students' inability to study independently. Communicative, social and prestige motives can be effective, but they are external in nature, and therefore it is desirable that they are combined with educational and professional motives of students (Badmaeva, 2004).

We are particularly interested in the results that educational and cognitive motives are interrelated with the democratic teaching style and communication based on interest in joint activities. Professional motives have a negative correlation with the laissez faire teaching style and communication-flirtation and the avoidance motives correlate with authoritarian teaching style and communication-intimidation.

The results indirectly confirm the research according to which the democratic (authoritative) style of the teacher is the most effective for the educational activities of students (Bota \& Tulbure, 2017; Dahar et al., 2010; Hanaa et al., 2018; Thijs \& Verkuyten, 2009). However, when analyzing the results of research showing that the authoritarian (autocratic) teaching style can be quite effective (Bota \& Tulbure, 2017; Dahar et al., 2010; Thijs \& Verkuyten, 2009), in our opinion, some clarification is required. According to our research, the preference for the authoritarian style may be related to the students' motivation of avoiding. Of course, this motivation also affects academic performance and other results of students, but it is negative, does not promote interest in learning and acts only under the threat 
of failure, mistakes, or failing marks (Badmaeva, 2004). In pedagogical practice, teachers need to take these factors into account, because, despite the fact that thatan authoritarian teaching style has some effect on the educational success of students (Bota \& Tulbure, 2017; Dahar et al., 2010), its use is undesirable in terms of students' motivation, as is the use of the laissez faire teaching style, and the styles of communication-intimidation and communication-flirtation.

Comparison of the peculiarities of the perception of the teaching style of teachers by future social and technical specialists showed that both groups regard the democratic teaching style equally positively. At the same time, while the students of social specializations perceived authoritarian and laissez faire styles as unambiguously negative, because they associate them with communication-distance, communication-intimidation and communication-flirtation, students of technical specializations did not. They perceive the authoritarian pedagogical style more positively and associate it with the style of pedagogical communication on the basis of interest in joint activities.

In addition, for specialists of social fields, the authoritarian teacher style correlates with motives of avoidance, and the laissez faire style negatively affects professional, academic, cognitive and social motives of the students. That is, these two teaching styles are not effective and not appropriate from the point of view of educational motivation of students of social specializations. For students of technical specializations, only the authoritarian pedagogical style relates to the motivation of learning (although these are external, they are positive motives correlation with communicative motives and motives of prestige), not the other leadership teaching styles. That is, the authoritarian style is not only more positively perceived by students of technical fields, but also is the only style effective in terms of influencing the motivation of learning, unlike students of the other group.

As for the styles of pedagogical communication, communication on the basis of interest in joint activities and amiability has the greatest influence on the motivation of future technical specialists, in particular the first style which is associated with such important motives as educational and cognitive. Both styles are correlated with the motive of creative self-realization. It is interesting that these two styles in the perception of students are associated with a democratic teaching style, but we found no influence of democratic style on the motivation of students of technical fields. It can be assumed that among the students' perception of these styles of pedagogical communication, democratic style and motivation of learning, there are additional factors that affect the manifestation of certain motives of students, but this requires additional research, as does determination of the reason 
why the students of technical specializations perceived the authoritarian pedagogical style quite positively in contrast to the students of social specializations.

\section{Conclusions}

The most appropriate teaching style is democratic, especially when combined with a style based on interest in joint activities with students. Students' perception of democratic style is the most positive. They associate it with communication based on interest in joint activities and amiable communication, while they have the opposite view of communication-flirtation and communication-intimidation. Students' perception of the teaching style is important for their learning motivation. In particular, the democratic teaching style and the style based on interest in joint activities are associated with such important motives of students as educational and cognitive. Undesirable teaching styles are authoritarian and ignoring ones. In particular, the first relates to the motives of avoidance, and the second has feedback from professional motives of students.

Comparison of the results of the survey of future specialists of social and technical fields allowed us to determine that both groups of students perceived a democratic style equally positively, and the laissez faire style negatively, whereas students of technical specializations consider the authoritarian style as more acceptable and positive than the students of social specializations. For students of social specializations, a style based on interest in joint activities and the democratic style are effective for learning motivation, while authoritarian and laissez faire styles are ineffective, whereas for students of technical specializations, the authoritarian style is the only style which is connected with positive motivations in the students. The results we obtained can be used by teachers in pedagogical interaction with students and could be a subject for further discussion regarding the perception of teachers by students and effective ways of motivation.

\section{References}

Badmaeva, N.Ts. (2004). Vliyanie motivatsionnogo faktora na razvitie umstvennyih sposobnostey [The influence of motivational factors on the development of mental abilities]. Ulan-Ude: Izdatelstvo VSGTU.

Barni, D., Russo, C., \& Danioni, F. (2018). Teachers' Values as Predictors of Classroom Management Styles: A Relative Weight Analysis. Frontiers in Psychology, 9: 1970. doi: 10.3389/fpsyg.2018.01970 
Bota, O.A., \& Tulbure, C. (2017). The Relationship Between Leadership Styles and Pupils' School Results. European Proceedings of Social and Behavioural Sciences, 23, 460-467. doi: 10.15405/epsbs.2017.05.02.56

Dahar, M.A., Faize, F.A., Niwaz, A., Hussain, M.A., \& Zaman, A. (2010). Relationship between the Leadership Styles and Academic Achievement at the Secondary Stage in Punjab. International Journal of Academic Research, 2(6), 459-462.

Doll, R.C. (1947). High-School Pupils' Attitudes toward Teaching Procedures. The School Review, 55(4), 222-227. doi: 10.1086/441390

Hanaa, E.S., Atyat, M.H., \& Heba, M.M. (2018). Relation between Students' Perception of Teaching Styles and Students' Academic Engagement in South Valley and Assiut Universities. Egyptian Journal of Health Care, 9(1), 187-204.

Kan-Kalik, V.A. (1987). Uchitelyu o pedagogicheskom obschenii [To the teacher about pedagogical communication]. Moscow: Prosveschenie.

Munir, F., \& Rehman, A. (2016). Most frequent teaching styles and students' learning strategies in public high schools of Lahore. Science International, 28(2), 1669-1674.

Nabaho, L., Oonyu, J., \& Aguti, J.N. (2017). Good teaching: Aligning student and administrator perceptions and expectations. Higher Learning Research Communications, 7(1). doi: $10.18870 /$ hlrc.v7i1.321

Noels, K.A., Clément, R., \& Pelletier, L.G. (1999). Perceptions of Teachers' Communicative Style and Students' Intrinsic and Extrinsic Motivation. The Modern Language Journal, 83, 23-34.

Sadik, F. (2016). Investigating primary school teachers' views about their classroom management behavior. Journal of Advances in Humanities and Social Sciences, 2(2), 76-84. doi:: 10.20474/jahss-2.2.2

Sobkin, V.S., \& Kalashinikova, E.A. (2016). On the Issue of Pedagogical Authority. Social Psychology And Society. 7(1), 88-107. doi: 10.17759/sps.2016070107

Thijs, J., \& Verkuyten, M. (2009). Students' Anticipated Situational Engagement: The Roles of Teacher Behavior, Personal Engagement, and Gender. The Journal of Genetic Psychology, 170(3), 268-286. doi: 10.1080/00221320903218323. 